\title{
IN VITRO CALLUS INDUCTION OF 'SHIRAZ' GRAPE (Vitis vinifera L.) USING DIFFERENT MEDIUM AND GROWTH REGULATOR COMBINATION
}

\author{
Ni Nyoman Nila Arieswari ${ }^{1}$, Ida Ayu Astarini ${ }^{*}$, Ni Putu Adriani Astiti ${ }^{1}$, and Jeremy \\ Pramana $^{2}$ \\ ${ }^{1}$ Biology Study Program, Faculty of Mathematics and Natural Sciences, Udayana University, Bali, \\ Indonesia \\ ${ }^{2}$ Hatten Wines, Bali, Indonesia \\ *Corresponding author: iaastarini@unud.ac.id
}

\begin{abstract}
One of grape cultivars widely used as raw material for wine production is 'Shiraz' cultivar. Propagation of this cultivar is necessary for the provision of grape as a wine making material in Bali. In vitro culture is an alternative propagation technique than can be employed to produce planting materials in a shorter time. This research aims to determine the most suitable medium and growth regulator combination in inducing grape cv. 'Shiraz' callus in vitro. The study was conducted from November 2017 until February 2018 at Plant Tissue Culture Laboratory, Biology Study Program, Udayana University. The explants used were young stem of grape cv. 'Shiraz' and the experiment was conducted using factorial design with two factors. The first factor was basal medium used (MS and WPM) and the second factor was IBA concentration $\left(0 ; 0.5\right.$ and $\left.1 \mathrm{mgL}^{-1}\right)$ and $\operatorname{BAP}\left(0,1\right.$ and $\left.2 \mathrm{mgL}^{-1}\right)$. The results showed that the highest percentage of callus induction (60\%) was obtained on WPM medium without growth regulator combination (control). However, the fastest time of callus appear was on MS medium $+2 \mathrm{mgL}^{-1} \mathrm{BAP}$ without IBA, which was 17 days after planting. The texture and color of callus resulted on this research were friable with white, greenish white, greenish yellow and green in color.
\end{abstract}

Keywords: growth hormone, BAP, IBA, WPM, MS

\section{INTRODUCTION}

Grape (Vitis vinifera L.) is one of edible fruit plants belong to Vitaceae family with woody stem, cylindrical shape, rough surface and brownish color. Since 4000 BC, grapevines have been cultivated in the Middle East, but processing into new beverages was discovered since $2500 \mathrm{BC}$ by the Egyptians (Tajuddin et al., 2012). Grape can be freshly consumed or processed into jelly, raisins, jams and the other.
One of grape cultivars that is widely used as raw material for wine production but not yet widely cultivated in Bali is 'Shiraz' cultivar. Propagation of this cultivar is necessary for the provision of grape as a wine making material. Therefore, an alternative propagation technique such as in vitro culture is needed to obtain plant materials in a relatively shorter time and produce more plantlets.

Plant propagation by tissue culture technique is influenced by various factors, 
including medium and growth regulator. for 30 seconds, washed by detergent for 3 Cerianingsih et al. (2015) reported grape minutes and running tap water for 30 minutes. cultivar 'Jestro Ag 86' propagation from Explants were then soaked in 0,2\% (w/v) axillary bud callus on MS medium added Dithane ${ }^{\circledR}$ and $0,1 \mathrm{ml}$ Nystatin for 30 minutes, with $1 \mathrm{mgL}^{-1}$ IBA and $2 \mathrm{mgL}^{-1}$ BAP. Lu followed by antibiotic for 30 minutes and (2005) reported that using of WPM medium shake manually. Explants were then surface was able to produce in vitro shoot sterilized with $50 \%$ Bayclin with addition of propagation in Vitis thunbergii plants 2 drop of Tween 20 for 3 minutes then compared with using of MS and NN medium. washes three times using sterilized distilled

The present report describes a procedure for the in vitro propagation of grape cv. 'Shiraz' from young stem explants on MS and WPM medium, also on growth regulators combination.

\section{MATERIALS AND METHODS}

The explants were obtained from Hatten Wines Vineyards located at Sanggalangit Village, Buleleng Regency, Bali, Indonesia. In vitro culture experiment was carried out at Plant Tissue Culture Laboratory, Biology Department, Faculty of Mathematics and Natural Sciences, Udayana University, Bali, Indonesia, from November 2017 to February 2018.

Young stems were used as explants. Sterilization explants following Siregar and Supriyanto (2014) with modification. Explants were sterilized using alcohol $70 \%$ water. All sterilization process was done on a laminar air flow cabinet.

The young stem explants were cut into $0.5 \mathrm{~cm}$ pieces and cultured on MS and WPM medium supplemented with $30 \mathrm{gL}^{-1}$ sucrose, $1.5 \mathrm{gL}^{-1}$ activated charcoal and $8 \mathrm{gL}^{-}$ 1 agar. The experiment employed Randomized Completely Design with two factors. First factor was basal medium used (MS and WPM). Second factor was IBA concentration $\left(0 ; 0.5\right.$ and $\left.1 \mathrm{mgL}^{-1}\right)$ and BAP (0, 1 and $\left.2 \mathrm{mgL}^{-1}\right)$. The cultures were incubated at $25^{\circ} \mathrm{C}$ under white fluorescent tubes at 18 hour light and 6 hour dark.

Variables observed were percentage of explants that produced callus, time of callus initiation, callus texture and color were measured following callus scoring of Andaryani (2010) with modifications. Data was analyzed using percentage formula like: 


$$
\% \text { Callus }=\frac{\sum X}{5} \times 100 \%
$$

Remarks:

$\mathrm{X}=$ Amount of explants that produced callus

$5=$ Replication

\section{RESULTS AND DISCUSSION}

The highest percentage of callus induction (60\%) was observed on WPM medium without growth regulator (control). Second highest (40\%) callus induction was observed on MS medium with the combination of $1 \mathrm{mgL}^{-1} \mathrm{IBA}$ and $1 \mathrm{mgL}^{-1}$ BAP and on WPM medium with combination of $1 \mathrm{mgL}^{-1} \mathrm{BAP}$ without IBA, on MS medium with the combination of 2 $\mathrm{mgL}^{-1}$ BAP without IBA, $1 \mathrm{mgL}^{-1}$ IBA and 2 $\mathrm{mgL}^{-1} \mathrm{BAP}$, and also on WPM medium with the combination of $0.5 \mathrm{mgL}^{-1}$ IBA and 1 $\mathrm{mgL}^{-1}$ BAP. Other treatment both on MS or WPM basal medium did not produce callus (Fig. 1).

Callus is defined as a set of amorphous cells caused by cell division continuously under in vitro conditions (Sudarmadji, 2003). Injury or excitatory wounds that occur in explants is the initial response of callus formation in which cells on explants will repair damaged cells
(Fowler, 1983). Leon (2001) described wounds that occur in cells or tissue explants will activate the form of self-defense on the plant tissue.

The use of basal media and combination of growth regulators influences the amount of callus induction. Ramdan (2011) explained that use of auxin in high concentrations can stimulate callus formation, whereas in low concentrations it can stimulate root formation. However, in the present research it was observed that using same amount of IBA and BAP or higher BAP concentrations leads to more callus induction. Results of this research was in accordance to Cerianingsih et al. (2015) who observed that the higher concentration of BAP than IBA were effective for callus induction in axillary bud explants of grape cv. 'Jestro Ag 86'. 


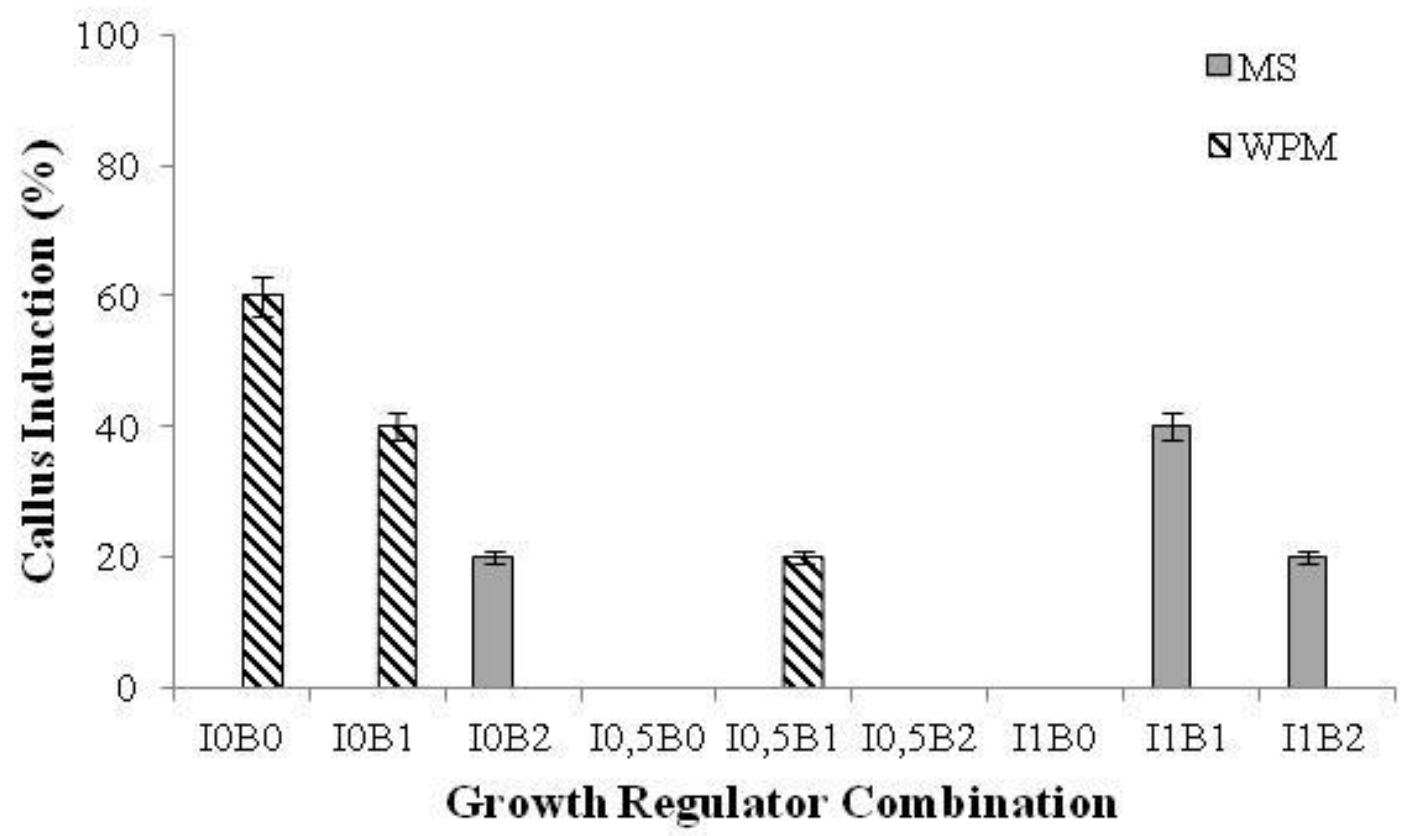

Fig. 1. The percentage of callus induction on young stem explants of grape cv. 'Shiraz' growth in MS and WPM medium containing different growth regulators combination

Even so, the fastest callus initiation IBA $+1 \mathrm{mgL}^{-1} \mathrm{BAP}(24 \mathrm{DAP})$. Furthermore, time was observed on MS medium with the callus initiation on WPM medium without combination of $2 \mathrm{mgL}^{-1}$ BAP without IBA, growth regulator was $25 \mathrm{DAP}$, followed by 1 i.e 17 days after planting (DAP); followed by $\mathrm{mgL}^{-1}$ BAP without IBA (30 DAP) and 0.5 combination of $1 \mathrm{mgL}^{-1} \mathrm{IBA}+2 \mathrm{mgL}^{-1} \mathrm{BAP} \quad \mathrm{mgL}^{-1} \mathrm{IBA}+1 \mathrm{mgL}^{-1} \mathrm{BAP}$ (41 DAP) (Table (22 DAP) and the combination of $1 \mathrm{mgL}^{-1} \quad 1$ ).

Table 1. Callus initiation (days after culture, DAC) in young stem explants of grape cv. 'Shiraz' using MS and WPM medium with growth regulators combination

\begin{tabular}{|c|c|c|c|c|c|c|c|c|c|}
\hline \multirow{2}{*}{ Treatment } & \multicolumn{9}{|c|}{ Callus Initiation (DAC) } \\
\hline & IOBO & I0B1 & I0B2 & I0.5BO & I0.5B1 & I0.5B2 & I1B0 & I1B1 & I1B2 \\
\hline MS & - & - & 17 & - & - & - & - & 24 & 22 \\
\hline WPM & 25 & 30 & - & - & 41 & - & - & - & - \\
\hline
\end{tabular}

Remarks : $(-)=$ callus not shown 
In this study, callus was appeared on 17 to 41 days after planting. Time of callus appearance is affected by growth regulators combination, medium and plant species used. Mahadi et al. (2016) on their study on callus induction of Calamansi (Citrus microcarpa) using 2,4-D and BAP reported that the higher concentrations of growth regulators combination can increase callus growth rate. But, this is not the case in this present research. Callus also produced in medium without growth regulator.

This research shows that the use of WPM medium can produce callus without growth regulators combination. WPM medium contains more $\mathrm{Ca}^{+}$than MS medium, i.e. in two forms of macronutrients $\left(\mathrm{Ca}\left(\mathrm{NO}_{3}\right)_{2} \cdot 2 \mathrm{H}_{2} \mathrm{O}\right.$ and $\left.\mathrm{CaCl}_{2} \cdot 2 \mathrm{H}_{2} \mathrm{O}\right)$. Meanwhile, on MS medium only present in the form of macronutrients $\mathrm{CaCl}_{2} \cdot 2 \mathrm{H}_{2} \mathrm{O}$. The function of $\mathrm{Ca}^{+}$are elongation and cell division, cell wall formation and stabilization, maintaining cell membrane structure and permeability, regulating some cell responses and also as regulator of carbohydrate translocation (Aranda-Peres et al., 2009; Soetan et al., 2010). Behbahani et al. (2011) also reported that WPM medium is a good choice especially in callus induction because of different $\mathrm{Ca}^{+}$and $\mathrm{PO}_{4}{ }^{-}$content.

Besides that, the variation of callus initiation time is also affected by ability of plant tissue to absorb nutrient in the medium.
This is related with tissue ability in the process of diffusion, osmosis and turgor pressure. Another factor that also affects the timing of callus induction is plant genotype. Some research on grape callus induction shows that variation of callus initiation time ranged from 2 to 8 weeks. Xu et al. (2005) reported that the callus of Muscadine grape was appear on 14 to 15 days after planting, while Purba et al. (2017) reported that grape callus was appear on 56 days after planting.

Color and texture of the callus become an indicator to determine the state of the cell whether it is dying or alive. Visually, callus texture can be divided into 3 types i.e. friable callus, intermediate callus and compact callus (Turhan, 2004). Callus produced can be green, light green, yellow green, yellow white, white, red, brown and the other. On this research, the calluses were friable with white, greenish white, greenish yellow and green (Fig. 2).

Table 2 shows callus score in this study. MS medium with $1 \mathrm{mgL}^{-1}$ IBA and 1 $\mathrm{mgL}^{-1}$ BAP and also $1 \mathrm{mgL}^{-1}$ IBA and 2 $\mathrm{mgL}^{-1}$ BAP resulting in friable white callus. The use of WPM medium without growth regulator combination and $0.5 \mathrm{mgL}^{-1} \mathrm{IBA}$ without BAP resulting in friable callus with greenish white in color. Use of WPM medium with $1 \mathrm{mgL}^{-1}$ BAP without IBA resulting in friable callus with greenish yellow in color, while MS medium with 2 
IN VITRO CALLUS INDUCTION OF 'SHIRAZ' GRAPE (Vitis vinifera L.) USING DIFFERENT MEDIUM AND GROWTH REGULATOR COMBINATION Ni Nyoman Nila Arieswari, Ida Ayu Astarini, Ni Putu Adriani Astiti, and Jeremy Pramana

$\mathrm{mgL}^{-1} \mathrm{BAP}$ without IBA resulting in friable green callus.

Table 2. Callus Score on in vitro growth grape cv. 'Shiraz' using MS and WPM medium with growth regulators combination

\section{Callus score}

\begin{tabular}{cccccccccc} 
Treatment & \multicolumn{10}{c}{} & I0B0 & I0B1 & I0B2 & I0.5B0 & I0.5B1 & I0.5B2 & I1B0 & I1B1 & I1B2 \\
\hline MS & 0 & 0 & 4 & 0 & 0 & 0 & 0 & 1 & 1 \\
WPM & 2 & 3 & 0 & 0 & 2 & 0 & 0 & 0 & 0 \\
\hline
\end{tabular}

Remarks: $0=$ no callus, $1=$ friable in texture and white in color, $2=$ friable in texture and greenish white, 3 = friable in texture and greenish yellow in color, $4=$ friable in texture and green in color

Compact callus was resulted from the formation of lignifications, whereas friable callus grows apart into small fragments (Yuliarti, 2010). Friable callus are highly suitable for use as a callus culture because it is easy to separate into single cells (Wijayanto, 2016). Compact callus is harder to separate because of its strong texture. But, compact callus may produce higher secondary metabolite which is often important for medicinal purpose.

Color of the callus is affected by light, pigmentation and explants (Hendaryono dan Wijayani, 1994). Callus color indicates the presence of chlorophyll in the tissues which is callus with green color indicates contain more chlorophyll (Arianti, 2015). The green color of the callus is due to the increased concentration of cytokinin. Cytokinin is able to activate protein synthesis and metabolism thereby inhibiting the overhaul of chlorophyll grains (Wattimena et al., 1992). 


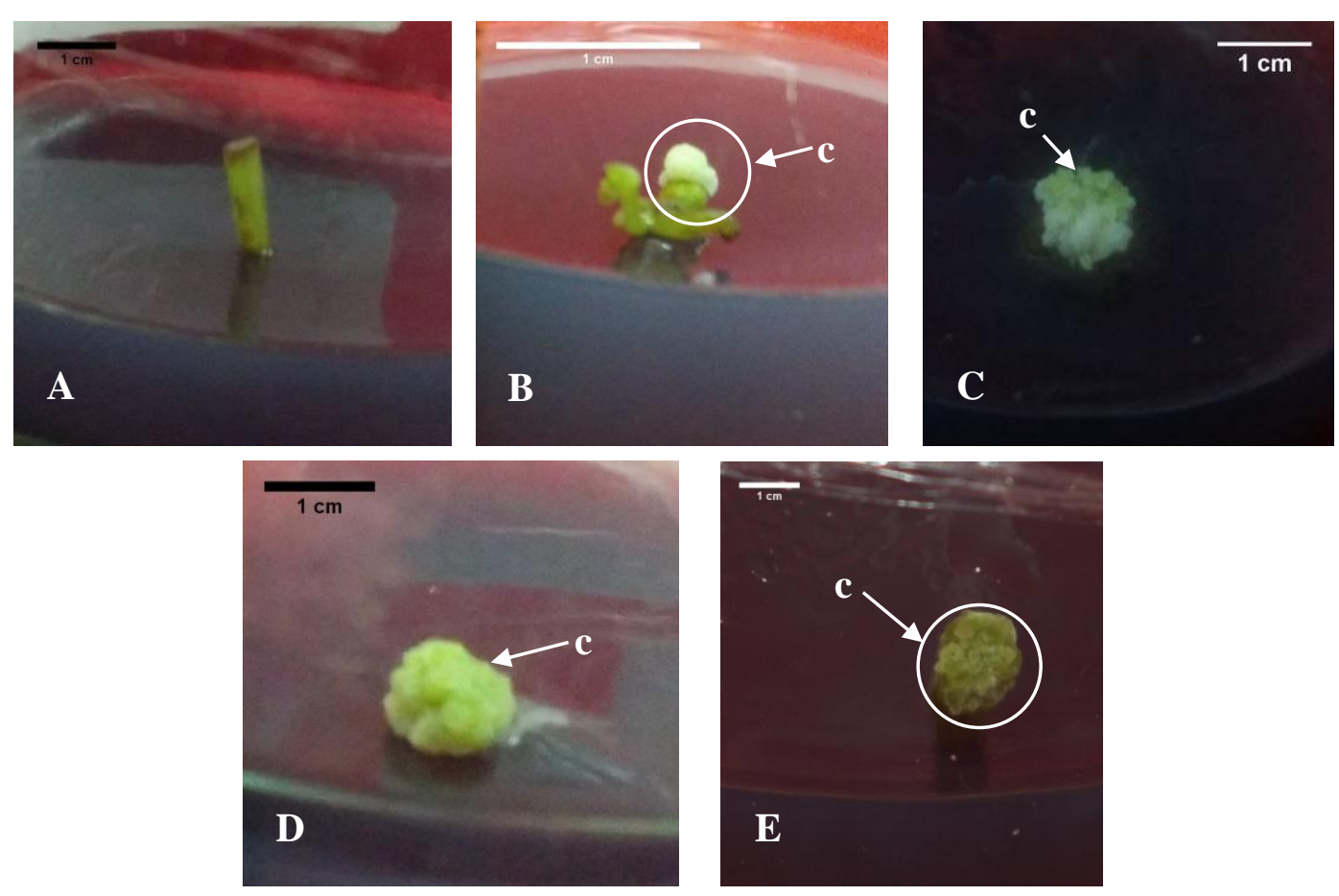

Fig. 2. Callus score on young stem explants of grape cv. 'Shiraz' using MS and WPM medium with growth regulators combination. A) score $0, \mathrm{~B})$ score 1 on MS + I1B1 and MS + I1B2, C) score 2 on WPM + I0B0 and WPM + I0.5B1, D) score 3 on WPM + I0B1, E) score

$$
4 \text { on MS + IOB2 }
$$

Remarks: $\mathrm{c}=$ callus

\section{CONCLUSIONS}

In conclusion, the use of WPM without growth regulator combination can produced the best callus among others with friable in texture and greenish white in color. This method can be used to provide grape cv. 'Shiraz' callus and sub-cultured on new medium to produce shoot or root.

\section{ACKNOWLEDGMENT}

The authors gratefully acknowledged support of Hatten Wines for the provision of grape cv. 'Shiraz' seedlings. Thanks also to Ni Luh Arpiwi, S.Si., M.Sc., Ph.D, Dr. Dra. Eniek Kriswiyanti, M.Si. and Dra. I Gusti Ayu Sugi Wahyuni, M.Si. for constructive criticism.

\section{REFERENCES}

Andaryani, S. (2010). Kajian Penggunaan Berbagai Konsentrasi BAP dan 2,4-D terhadap Induksi Kalus Jarak Pagar (Jatropha curcas L.) secara in vitro. (Skripsi). Universitas Sebelas Maret. Surakarta. 
Aranda-Peres, A. N., Pereim Peres, L. E., Higashi, E. N., \& Martinelli, A. P. (2009). Adjustment of Mineral Elements in the Culture Medium for the Micropropagation of Three Vriesea bromeliads from the Brazilian Atlantic Forest : The importance of Calcium. HortScience. 44(1): 106-112.

Arianti, A. M. (2015). Pengaruh Berbagai Konsentrasi PEG (Polyethylen Glicol) 6000 terhadap Kualitas dan Kuantitas Kalus serta Uji Kualitatif Metabolit Sekunder Vernodalin Pada Kalus Afrika (Vernonia amygdalina). Skripsi. Jurusan Biologi, Fakultas Sains dan Teknologi, Universitas Islam Negeri Maulana Malik Ibrahim Malang.

Behbahani, M., Shanehsazzadeh, M., \& Hessami, M. J. (2011). Optimization of Callus and Cell Suspension Cultures of Barringtonia racemosa (Lecythidaceae family) for Lycopene Production. Scientia Agricola. 68(1): 69-76.

Cerianingsih, M. W., Astarini, I. A., \& Nurjaya, I. G. M. O. (2015). Pengaruh Kombinasi Zat Pengatur Tumbuh Indole-3-Butyric Acid (IBA) dan 6Benzil Amino Purin (BAP) Pada Kultur In Vitro Tunas Aksilar Anggur (Vitis vinifera L.) Varietas Prabu Bestari dan Jestro Ag 86. Jurnal Metamorfosa. 2(1): 108.

Fowler, M. W. (1983). Commercial Application and Economic Aspects of Mass Plant Cell Culture, dari Mantell, S. H. Smith, H. (ed). Plant Biotechnology. Cambridge University Press, London. pp. 3-38.

Hendaryono, D. P. S., \& Wijayani, A. (1994). Teknik Kultur Jaringan Pengenalan dan Petunjuk Perbanyakan Tanaman secara Vegetatif-Modern. Yogyakarta: Kanisius.

Leon, J. (2001). Would Signalling in Plants. Journal of Experimental Botany. 52(354): 1-9.
Lu, M. C. (2005). Micropropagation of Vitis thunbergii Sieb. et Zucc., a Medicinal Herb, Through High-frequency Shoot Tip Culture. Scie. Hort. 107: 64069.

Mahadi, I., Syafi'I, W., \& Sari, Y. (2016). Induksi Kalus Jeruk Kasturi (Citrus microcarpa) Menggunakan Hormon 2,4-D dan BAP dengan Metode In Vitro. Jurnal Ilmu Pertanian Indonesia. 21(2): 84-89.

Purba, R. V., Yuswanti, H., \& Astawa, I. N. G. (2017). Induksi Kalus Eksplan Daun Tanaman Anggur (Vitis vinifera L.) Dengan Aplikasi 2,4-D Secara In Vitro. E-Jurnal Agroekoteknologi Tropika. 6(2): 218-228.

Ramdan. (2011). Kultur Daun dan Pangkal Batang In Vitro Anggrek Bulan Raksasa (Phalaenopsis gigantea J.J.Smith) pada Beberapa Media Kultur Jaringan. (Skripsi). Departemen Agronomi dan Hortikultura, Fakultas Pertanian, Institut Pertanian Bogor.

Siregar, A. S., \& Supriyanto, A. (2014). Inisiasi Kultur Meristem Anggur In Vitro. Prosiding Seminar Nasional Perhoti 2014. Malang, Jawa Timur.

Soetan, K., Olaiya, C., \& Oyewole, O. (2010). The Importance of Mineral Elements for Humans, Domestic Animals and Plants: A Review. African Journal of Food Science. 4: 200-222.

Sudarmadji. (2003). Penggunaan Benzil Amino Purine pada Pertumbuhan Kalus Kapas Secara In Vitro. Buletin Teknik Pertanian. 8(1): 8-10.

Tajuddin, R., Suwastika, I. N., \& Muslimin. (2012). Organogenesis Tanaman Anggur Hijau (Vitis vinifera L.) Pada Medium MS Dengan Penambahan IAA (Indole Acetid Acid) Dan Berbagai Konsentrasi BAP (Benzil Amino Purin). Jurnal Natural Science. 1(1): 63-73.

Turhan, H. (2004). Callus Induction and Growth in Transgenic Potato Genotype. African Journal of Biotechnology. 3(8): 375-378. 
Wattimena, G. A., Gunawan, L. W., Mattjik, N. A., Syamsudin, E., Wiendi, N. M. A., \& Ernawati, A. (1992). Bioteknologi Tanaman. Bogor: Laboratorium Kultur Jaringan Tanaman Pusat Antar Universitas Bioteknologi IPB - Lembaga Sumberdaya Informasi IPB.

Wijayanto, D. (2016). Induksi Kalus

Embriogenik Jenis Eksplan Bulbil Bawang Putih cv. Tawangmangu Baru pada Beberapa Kombinasi Zat Pengatur Tumbuh. Skripsi. Departemen Argonomi dan Hortikultura, Fakultas Pertanian, Institut Pertanian Bogor.

Xu, X., Lu, J., Ren, Z., Wang, H., \& Leong, S. (2005). Callus Induction and Somatic Embryogenesis in Muscadine and Seedless Bunch Grapes (Vitis) from Immature Ovule Culture. Proc. Fla. State Hort. Soc. 118: 260-262.

Yuliarti, N. (2010). Kultur Jaringan Tanaman Skala Rumah Tangga. Jakarta: Andi Publisher. 